\title{
CYTOGENETIC DAMAGE IN TURKISH COKE OVEN WORKERS EXPOSED TO POLYCYCLIC AROMATIC HYDROCARBONS: ASSOCIATION WITH CYP1A1, CYP1B1, EPHX1, GSTM1, GSTT1, AND GSTP1 GENE POLYMORPHISMS
}

\author{
Ahmet Oguz ADA ${ }^{1 *}$, Canan DEMIROGLU²*, Meltem YILMAZER ${ }^{2}$, Halit Sinan SUZEN ${ }^{1}$, Ali Eba \\ DEMIRBAG $^{3}$, Sibel EFE ${ }^{4}$, Yilmaz ALEMDAR ${ }^{4}$, Mumtaz ISCAN ${ }^{1}$, and Sema BURGAZ ${ }^{2}$
}

Department of Toxicology, Faculty of Pharmacy, Ankara University, Tandogan ${ }^{1}$, Department of Toxicology, Faculty of Pharmacy, Gazi University, Etiler², Gastrointestinal Surgery Department, Yuksek Ihtisas Hospital, Sihhiye ${ }^{3}$, Ankara, Eregli Iron and Steel Works Co., Karadeniz Eregli4, Turkey

\author{
Received in November 2012 \\ CrossChecked in April 2013 \\ Accepted in April 2013
}

\begin{abstract}
The aim of this study was to determine the frequencies of chromosomal aberrations (CA) and cytochalasinblocked micronuclei (CBMN) in peripheral blood lymphocytes from Turkish coke oven workers and the influence of CYP1A1, CYP1B1, EPHX1, GSTM1, GSTT1, and GSTP1 gene polymorphisms on these biomarkers. Cytogenetic analysis showed that occupational exposure significantly increased the CA and CBMN frequencies. Gene polymorphisms, on the other hand, did not affect CA or CBMN in either exposed or control subjects. However, due to the limited sample size, our findings need to be verified in future studies with a larger sample.
\end{abstract}

KEY WORDS: chromosomal aberrations, biomarkers, micronuclei, occupational exposure

Coke oven plants are a major source of emissions that contain complex mixtures of genotoxic and carcinogenic pollutants. Although the chemical content of these mixtures changes with the technology used in coke production, all contain polycyclic aromatic hydrocarbons (PAHs), which are released into the environment when coal is pyrolysed into coke. Moreover, PAHs with four or more aromatic rings are considered to be human carcinogens (1). The International Agency for Research on Cancer (IARC) has reported an increase in cancer incidence, lung cancer in particular, in workers with high and longterm exposure to coke oven emissions (2).

\footnotetext{
* The first two authors contributed equally to this article.
}

Monitoring biological effects as a measure of internal effective dose can provide relevant information for the assessment of cancer risks. Cytokinesis-block micronucleus (CBMN), chromosomal aberrations (CA), and sister chromatid exchanges (SCE) have been applied as biomarkers of exposure and early effects of genotoxic carcinogens. Epidemiological studies suggest that increased frequency of CA is predictive of an increased risk of cancer (3). CBMN assay has emerged as a maturing biomarker of chromosomal damage relevant to cancer in recent years. A recent Human MicroNucleus (HUMN) group study (4) with 6718 subjects has shown that increased CBMN frequency in peripheral blood lymphocytes 
can predict cancer risk in humans. Murgia et al. (5) found that individuals with high CBMN had a significantly higher cancer death risk than individuals with low CBMN.

A recent meta-analysis (6) of chromosomal damage and occupational exposure to PAHs revealed that cytogenetic end-points such as CBMN, CA, and SCE might be indicators of early effects in workers exposed to PAHs. Various gene polymorphisms that could modulate response to genotoxicity have already been addressed in several studies during the last decade (7).

Several polymorphisms of enzymes involved in PAH metabolism, DNA repair, and/or folatemetabolism may influence CBMN formation, but this association is rather complex. In the presence of multiple external and internal exposures, and the large number of chromosomal alterations, CBMN formation is inevitable. Iarmacovai et al. (8) have shown that EPHX1, GSTT1, and GSTM1 polymorphisms modulate chromosomal damage in individuals exposed to genotoxic agents as well as in unexposed individuals. Others $(9,10)$ studied the effects of polymorphisms of genes involved in the metabolism of carcinogens on biomarkers of exposure such as urinary 1hydroxypyrene (1-OHP) or DNA and protein adducts in populations occupationally exposed to PAHs. However, there are but a few studies on the effects of PAH metabolising enzyme polymorphisms on biomarkers such as CBMN in coke oven workers (1118). In addition, only one study (14) investigated the effects of genetic polymorphisms of PAH metabolising enzymes on CA in coke oven workers.

The aim of our study was to assess PAH exposure of Turkish coke oven workers through CA and CBMN frequencies in peripheral lymphocytes and see whether the CYP1A1, CYP1B1, EPHX1, GSTM1, GSTP1, and GSTT1 gene polymorphisms affected these biomarkers.

\section{SUBJECTS AND METHODS}

\section{Subjects and sampling}

All study subjects were involved in our previous studies $(10,19)$. Participation in this research was voluntary and all subjects were informed about the aims of the study. They gave their informed consent prior to enrolment according to the Helsinki
Declaration. Questionnaire data contained items about demography, work history, job description, protective measures, smoking status, dietary information (alcohol consumption, fruit, grilled meat, vitamins, etc.), and medication (past and present), but only age and smoking have been investigated as variables in this study. Persons who had worked for less than three months or had received medical or radiological treatment or vaccination within three months before sampling were excluded.

The study eventually enrolled a hundred male workers. The exposed group consisted of 50 male workers employed in a Turkish iron and steel plant in Eregli, Zonguldak. Eight were top-oven workers (tar chasers and lidmen) and 42 were side-oven workers (heaters, quenching car operators, pushers, machine operators, oven repairmen, supervision, maintenance). The control group consisted of 50 packaging and energy department workers from the same plant, occupationally unexposed to PAHs. Workers from all three shifts were included in this study. All wore protective clothing, helmets, shoes, gloves, and masks while on duty.

Post shift urine samples were collected in a PVC container without preservatives and kept at $-20{ }^{\circ} \mathrm{C}$ until analysis, as described in our earlier study (10).

Coded venous blood samples were collected into heparinised tubes at the same time as the urine samples and were processed within $5 \mathrm{~h}$ of collection.

\section{CBMN frequencies in lymphocytes}

Blood cultures consisted of a RPMI 1640 medium (Biological Industries, Beit Ha Emek, Israel) supplemented with $20 \%$ foetal calf serum, $2 \%$ phytohaemagglutinine (PHA-L), L-glutamine, and 13 to 14 drops of whole blood. All experiments were carried out in duplicate. Sample cultures were incubated at $37^{\circ} \mathrm{C}$ for $72 \mathrm{~h}$. Binucleated cells were accumulated by adding cytochalasin $\mathrm{B}$ at a final concentration of $6 \mu \mathrm{g} \mathrm{mL}^{-1}$ at $44 \mathrm{~h}$ following the initiation of the culture (20).

Trisodium citrate (1\%) was used for a mild hypotonic effect. Slides were stained with MayGrünwald and Giemsa. CBMN frequency was examined by microscopy in 2,000 binucleated cells with well-preserved cytoplasm using the magnification of 1000x. Micronuclei were scored according to the criteria described by Fenech (20) only in binuclear lymphocytes in which the nuclei were of equal size and of the same colour. The diameter of the micronuclei was between $1 / 16$ and $1 / 3$ of the main nuclei and there 
was no link between the two via a nucleoplasmic bridge. CBMN frequencies were expressed in permillage (\%o).

The Nuclear Division Index (NDI), a cell proliferation index, was calculated according to Eastmond and Tucker (21). Slide scorer was not aware of the exposure status of the subjects.

\section{CA frequencies in lymphocytes}

Fourteen drops of blood were added into a $5 \mathrm{~mL}$ RPMI 1640 medium supplemented with $20 \%$ foetal calf serum and $2 \%$ PHA-L on the day of sampling. The cultures were incubated in the dark at $37^{\circ} \mathrm{C}$ for $48 \mathrm{~h}$. Three hours before the harvest, colchicine $\left(0.05 \mu \mathrm{g} \mathrm{mL}^{-1}\right)$ was added to the culture. The cells were collected by centrifugation, re-suspended in a hypotonic solution $\left(0.075 \mathrm{mmol} \mathrm{L}^{-1}\right.$ of KCl) for $20 \mathrm{~min}$ and fixed in acetic acid:methanol (1:3). Slides were prepared by air-drying and stained with a $5 \%$ Giemsa solution.

The scoring of chromosomal aberrations included chromatid breaks, acentric fragments, dicentrics, and gaps. The frequencies of aberrant cells with or without gaps were statistically analysed as described below. A total of 100 well-spread metaphases with 46 chromosomes were examined per donor. Slide scorer was not aware of the exposure status of the subjects.

\section{Genotyping}

DNA was isolated from blood samples using a Promega Corporation DNA isolation kit (Madison, WI, USA). The CYP1A1 exon 7 (Ile462 Val) (rs1048943) polymorphism was determined using the polymerase chain reaction-restriction fragment length polymorphism (PCR/RFLP) method described by Cascorbi et al. (22) and the CYP1B1 exon 3 (Asn453Ser) (rs1800440) polymorphism using the PCR/RFLP method described by Bailey et al. (23). To determine the EPHXI exon 3 (Tyr113His) (rs1051740) and EPHX1 exon 4 (His139Arg) (rs2234922) polymorphisms we used the PCR/RFLP method described by Smith and Harrison (24). The GSTMI and the GSTT1 gene deletions were determined using the multiplex PCR method of Abdel-Rahman et al. (25). The GSTP1 exon 5 (Ile105Val) (rs1695) and GSTP1 exon 6(Ala114Val)(rs1138272) polymorphisms were determined using the PCR/RFLP method described by Park et al. (26).

For quality control, laboratory staff were blinded to the sources of DNA samples and $10 \%$ of the samples were retested at random, showing $100 \%$ concordance. Two authors independently reviewed all of the agarose gels and genotype data entries.

\section{Statistical analysis}

The deviation from the Hardy-Weinberg equilibrium (HWE) was tested by comparing the observed and expected genotype frequencies using the chi-square test. Data were analysed with SPSS for Windows, version 11.5 (SPSS Inc., Chicago, IL, USA).

To determine the normality of distribution of continuous variables we used the Shapiro-Wilk test.

Data are shown as mean \pm standard deviation (SD) or median (and range), where applicable. Betweengroup differences in means were compared with Student's $t$-test and in medians with the MannWhitney U test. Nominal data were analysed with the chi-square test. Degrees of association between continuous variables were evaluated with Spearman's correlation test, which was also used to see if there were any associations between CBMN / total CA frequency data with or without gaps and the corresponding urinary 1-OHP levels, which we published recently (10). Multiple linear regression analysis was used to see if there were significant differences in CA or CBMN between coke oven workers and controls when adjusted for age, smoking, urinary 1-hydroxypyrene (1-OHP), and polymorphisms. Log-transformed linear regression analysis was used for dependent variables that were not normally distributed. Coefficients of regression and $95 \%$ confidence intervals were calculated for all independent variables. A $p$ value of less than 0.05 was considered statistically significant.

\section{RESULTS}

Table 1 summarises the demographic data of the coke oven workers and controls. Subjects smoking more than 20 cigarettes per day and non-smoking subjects were more prevalent in controls and coke oven workers, respectively $(p<0.05)$. Urinary 1-OHP levels as indicators of PAH exposure were about 3.5 times higher in coke oven workers than controls $(p<0.001)$, as described elsewhere (10).

Table 2 shows CBMN frequencies in peripheral blood lymphocytes by age, smoking status, and duration of exposure. Median CBMN frequency in coke oven workers was significantly higher than in 
Table1 Demographic and lifestyle data for coke oven workers and controls*

\begin{tabular}{lccc}
\hline Variables & Controls & $\begin{array}{c}\text { Coke oven } \\
\text { Workers }\end{array}$ & $\boldsymbol{p}$ \\
\hline$N$ & 50 & 50 & \\
\hline Age / mean \pm SD & $38.7 \pm 9.5$ & $40.4 \pm 6.6$ & 0.301 \\
\hline Smoking status / $(\%)$ & $7(14.0)$ & $18(36.0)$ & 0.021 \\
\hline Non-smokers & $10(20.0)$ & $10(20.0)$ & 1.000 \\
\hline 1 to 10 cigarettes per day & $17(34.0)$ & $19(38.0)$ & 0.677 \\
\hline 11 to 20 cigarettes per day & $16(32.0)$ & $3(6.0)$ & $<0.001$ \\
\hline 20 cigarettes per day & - & $16(1$ to 25$)$ & - \\
\hline Duration of exposure / year; median (range) & 0.23 & 0.82 & $<0.001$ \\
\hline
\end{tabular}

* data taken from Ada et al. (10)

Table 2 CBMN frequencies (\%o) by age, smoking, and duration of exposure in control and coke oven workers

\begin{tabular}{|c|c|c|c|c|c|c|c|}
\hline \multirow[b]{2}{*}{ Variables } & \multicolumn{3}{|c|}{ Controls } & \multicolumn{3}{|c|}{ Coke oven workers } & \multirow[b]{2}{*}{$p^{*}$} \\
\hline & $n$ & $\begin{array}{l}\text { Median } \\
\text { (Range) }\end{array}$ & $\boldsymbol{p}^{\dagger}$ & $n$ & Median (Range) & $\boldsymbol{p}^{\dagger}$ & \\
\hline All & $49^{a}$ & $6(1$ to 15$)$ & - & $49^{a}$ & $12(4$ to 38$)$ & - & $<0.001$ \\
\hline Age groups / year & & & 0.331 & & & 0.125 & \\
\hline$\leq 40$ & 20 & $6(1$ to 11$)$ & & 19 & $15(4$ to 28$)$ & & $<0.001$ \\
\hline$\geq 41$ & 29 & $6(2$ to 15$)$ & & 30 & $10.5(4$ to 38$)$ & & $<0.001$ \\
\hline Smoking status & & & 0.291 & & & 0.248 & \\
\hline Nonsmokers & 7 & $6(2$ to 10$)$ & & 18 & 11 (4 to 23$)$ & & 0.002 \\
\hline Smokers & 42 & $6(1$ to 15$)$ & & 31 & $14(4$ to 38$)$ & & $<0.001$ \\
\hline Duration of exposure / year & & & - & & & 0.699 & \\
\hline$<20$ & - & - & & 36 & $13(4$ to 38$)$ & & - \\
\hline$\geq 20$ & - & - & & 13 & $11(7$ to 21$)$ & & - \\
\hline
\end{tabular}

${ }^{a} C B M N$ data for one subject in the exposed and control group were not available

+ Comparisons within both control and coke oven workers

* Comparisons between control and coke oven workers

Table 3 Frequencies (\%) of chromosomal aberrations without gaps (CA-gap) by age, smoking and duration of exposure in controls and coke oven workers

\begin{tabular}{|c|c|c|c|c|c|c|c|}
\hline \multirow[b]{2}{*}{ Variables } & \multicolumn{3}{|c|}{ Controls } & \multicolumn{3}{|c|}{ Coke oven workers } & \multirow[b]{2}{*}{$p^{*}$} \\
\hline & $n$ & $\begin{array}{l}\text { Median } \\
\text { (Range) }\end{array}$ & $p^{\dagger}$ & $n$ & $\begin{array}{l}\text { Median } \\
\text { (Range) }\end{array}$ & $p^{\dagger}$ & \\
\hline All & $45^{\mathrm{a}}$ & $0(0$ to 1$)$ & - & $48^{\mathrm{a}}$ & $0.5(0$ to 7$)$ & - & $<0.001$ \\
\hline Age groups / year & & & 0.771 & & & 0.347 & \\
\hline$\leq 40$ & 20 & $0(0$ to 1$)$ & & 19 & $1(0$ to 7$)$ & & 0.016 \\
\hline$\geq 41$ & 25 & $0(0$ to 1$)$ & & 29 & $0(0$ to 2$)$ & & 0.008 \\
\hline Smoking status & & & 0.470 & & & 0.380 & \\
\hline Nonsmokers & 7 & $0(0$ to 1$)$ & & 17 & $0(0$ to 7$)$ & & 0.619 \\
\hline Smokers & 38 & $0(0$ to 1$)$ & & 31 & $1(0$ to 3$)$ & & $<0.001$ \\
\hline Duration of exposure / year & & & - & & & 0.527 & \\
\hline$<20$ & - & - & & 34 & $1(0$ to 7$)$ & & \\
\hline$\geq 20$ & - & - & & 14 & $0(0$ to 2$)$ & & \\
\hline
\end{tabular}

a Chromosomal aberration data for five subjects in the control group and two subjects in the exposed group were not available.

+ Comparisons within both control and coke oven workers.

* Comparisons between control and coke oven workers. 
controls, but within-group differences were not significant in regard to age and smoking in either group or to exposure history in coke oven workers. Mean \pm SD of NDI values for exposed $(2.14 \pm 0.05)$ and control subjects $(2.14 \pm 0.04)$ were similar $(p>0.05)$.

Chromosomal aberrations mainly consisted of chromatid breaks and gaps. Table 3 shows that the overall frequencies of total aberrant cells without gaps (CA-gap) were significantly higher in coke oven workers than controls $(p<0.001)$. They were also significantly higher in coke oven workers aged below $40(p<0.05)$ and those above 41 years $(p<0.01)$ compared to control subgroups. Similar was found for smoking coke oven workers compared to smoking controls $(p<0.001)$. However, similar to CBMN, no significant effect on CA-gap frequencies was found for age and smoking within either group or for exposure history in coke oven workers.

Findings for aberrant cells with gaps (CA+gap) were similar to those for CA-gap (Table 4).

The two groups did not differ in the distribution of genotypes (data not shown), as it was in good agreement with the Hardy-Weinberg equilibrium. There were no homozygous mutant CYPlAl Val/Val and GSTP $1 \mathrm{Val} / \mathrm{Val}$ genotypes in either group and no $E P H X 1 \mathrm{His} / \mathrm{His}$ genotypes in the control group. Due to a small number of $C Y P 1 B 1, G S T P 1$, and EPHXI homozygous mutant genotypes in the coke oven workers $(C Y P 1 B 1 \mathrm{Ser} / \mathrm{Ser} n=2$, GSTP 1 Val/Val $n=$ 2, EPHX1 His/His $n=2, E P H X 1 \operatorname{Arg} / \operatorname{Arg} n=3)$ and controls (CYP1B1 Ser/Ser $n=3$, GSTP 1 Val/Val $n=$ 2, EPHX1 Arg/Arg $n=3$ ), heterozygous and homozygous mutant genotypes were combined for statistical analysis.

Controls did not differ in CBMN, CA-gap, or $\mathrm{CA}+$ gap frequencies between the genotypes (Table $5)$.

In coke oven workers, the only significant difference was found for CBMN frequency, which was significantly higher in the wild-type allele carriers than in mutant allele carriers of the exon7 of CYP1A1 gene ( $p=0.015$; Table 6 ).

We found no significant correlation between urinary 1-OHP levels and CBMN, CA-gap or CA + gap frequencies in either group (Table 7).

Multiple linear regression analyses after adjustment for age, smoking status, 1-OHP, and genotypes showed that exposure to coke oven emissions significantly increased CBMN, CA-gap, and CA+gap frequencies $(p<0.05$; Table 8$)$. Other independent variables did not significantly affect either of the three parameters.

\section{DISCUSSION}

Epidemiological studies have shown that long-term exposure to PAHs significantly increases the risk of developing lung cancer in coke oven workers (2). Our worker population was recruited from the Turkey's largest iron and steel production plant in Erdemir. With 159 coke ovens, its coke capacity is about one million tonnes per year.

As chromosomal changes and genetic instability are the major causes of carcinogenesis, identifying reliable cytogenetic biomarkers for high cancer risk is an important task for public health services (27). Biomarkers used in our study have been demonstrated as reliable for predicting increased risk of cancer in humans $(3,4)$.

Previously we had established coke oven workers' exposure to PAH by determining urinary 1-OHP excretion $(10,19)$. Urinary 1-OHP is a good biomarker of exposure to PAHs, as it reflects all exposure routes (28). Our measurements were in line with those of industrialised western countries $(15,18,28-30)$ and three to 10 times lower than in Polish, Chinese, Estonian, or Taiwanese workers $(16,17,31,32)$.

Our cytogenetic analysis shows that occupational exposure at the coke oven significantly elevated the frequencies of CA and CBMN in peripheral blood lymphocytes. These results are in line with earlier CBMN reports $(12,13,16,17)$, but in contrast with Van Delft et al. (11), who found no significant increase in CBMN frequency among coke oven workers.

Increased CA frequencies in coke oven workers have also been reported earlier $(14,33)$. However, Siwinska et al. (17) found no association between occupational exposure and CA, even though 1-OHP levels were about nine times higher than in our coke oven workers. Furthermore, Forni et al. (30) found no alteration in CA and CBMN frequencies in coke oven workers with 1-OHP levels similar to ours. All these contradictions could be due to different sample sizes, composition of cohorts (including age, smoking, and diet), methodology, and occupational exposure to genotoxic chemicals other than PAHs.

The only Turkish study before ours (34) demonstrated significantly higher CA frequencies in iron and steel plant workers from units other than the coke oven unit. However, the study lacks any PAH exposure data for comparison with our findings.

In this study, we found no correlation between urinary 1-OHP and $\mathrm{CA}$ and $\mathrm{CBMN}$ frequencies. This may be explained by the fact that CA and CBMN 
Table 4 Frequencies (\%) of chromosomal aberrations with gaps (CA+gap) by age, smoking and duration of exposure in controls and coke oven workers

\begin{tabular}{|c|c|c|c|c|c|c|c|}
\hline \multirow[b]{2}{*}{ Variables } & \multicolumn{3}{|c|}{ Controls } & \multicolumn{3}{|c|}{ Coke oven workers } & \multirow[b]{2}{*}{$p^{*}$} \\
\hline & $n$ & $\begin{array}{l}\text { Median } \\
\text { (Range) }\end{array}$ & $p^{\dagger}$ & $n$ & $\begin{array}{l}\text { Median } \\
\text { (Range) }\end{array}$ & $p^{\prime}$ & \\
\hline All & $45^{\mathrm{a}}$ & $1(0$ to 5$)$ & - & $48^{\mathrm{a}}$ & $3(0$ to 9$)$ & - & $<0.001$ \\
\hline Age groups / year & & & 0.652 & & & 0.577 & \\
\hline$\leq 40$ & 20 & $1(0$ to 4$)$ & & 19 & $3(0$ to 9$)$ & & 0.012 \\
\hline$\geq 41$ & 25 & $1(0$ to 5$)$ & & 29 & $3(0$ to 7$)$ & & $<0.001$ \\
\hline Smoking status & & & 0.331 & & & 0.677 & \\
\hline Non-smokers & 7 & $2(0$ to 4$)$ & & 17 & $2(0$ to 9$)$ & & 0.383 \\
\hline Smokers & 38 & $1(0$ to 5$)$ & & 31 & $3(0$ to 8$)$ & & $<0.001$ \\
\hline Duration of exposure / year & & & & & & 0.809 & \\
\hline$<20$ & - & - & & 34 & $3(0$ to 9$)$ & & \\
\hline$\geq 20$ & - & - & & 14 & $2(1$ to 5$)$ & & \\
\hline
\end{tabular}

${ }^{a}$ Chromosomal aberration data for five subjects in control group, and two subjects in exposed group were not available.

+ Comparisons within both control and coke oven worker groups.

* Comparisons between control and coke oven worker groups.

Table 5 CBMN, (CA-gap), and (CA+gap) frequencies in controls by genotype

\begin{tabular}{|c|c|c|c|c|c|c|c|c|c|}
\hline \multirow[b]{2}{*}{ Genotypes } & \multicolumn{3}{|c|}{ CBMN / \%o } & \multicolumn{3}{|c|}{ CA-gap / \% } & \multicolumn{3}{|c|}{$\mathrm{CA}+$ gap / \% } \\
\hline & $n$ & $\begin{array}{l}\text { Median } \\
\text { (Range) }\end{array}$ & $p$ & $n$ & $\begin{array}{l}\text { Median } \\
\text { (Range) }\end{array}$ & $p$ & $n$ & $\begin{array}{l}\text { Median } \\
\text { (Range) }\end{array}$ & $p$ \\
\hline CYP1A1 exon7 & & & 0.514 & & & 0.658 & & & 1.000 \\
\hline Ile/Ile & 45 & $6(1$ to 15$)$ & & 41 & $0(0$ to 1$)$ & & 41 & $1(0$ to 5$)$ & \\
\hline $\mathrm{Ile} / \mathrm{Val}+\mathrm{Val} / \mathrm{Val}$ & 4 & $5.5(3$ to 7$)$ & & 4 & $0(0$ to 0$)$ & & 4 & $1(0$ to 3$)$ & \\
\hline$C Y P 1 B 1$ exon 3 & & & 0.513 & & & 0.094 & & & 0.795 \\
\hline Asn/Asn & 22 & $5.5(3$ to 11$)$ & & 22 & $0(0$ to 1$)$ & & 22 & $1(0$ to 3$)$ & \\
\hline Asn/Ser+Ser/Ser & 23 & $6(1$ to 15$)$ & & 23 & $0(0$ to 1$)$ & & 23 & $1(0$ to 5$)$ & \\
\hline GSTM1 & & & 0.896 & & & 0.487 & & & 0.115 \\
\hline Null & 24 & $6(2$ to 15$)$ & & 21 & $0(0$ to 1$)$ & & 21 & $1(0$ to 5$)$ & \\
\hline Positive & 25 & $6(1$ to 13$)$ & & 24 & $0(0$ to 1$)$ & & 24 & $1(0$ to 4$)$ & \\
\hline GSTT1 & & & 0.889 & & & 0.493 & & & 0.298 \\
\hline Null & 9 & $7(3$ to 11$)$ & & 8 & $0(0$ to 0$)$ & & 8 & $0.5(0$ to 3$)$ & \\
\hline Positive & 40 & $6(1$ to 15$)$ & & 37 & $0(0$ to 1$)$ & & 37 & $1(0$ to 5$)$ & \\
\hline GSTP1 exon5 & & & 0.258 & & & 0.417 & & & 0.236 \\
\hline Ile/Ile & 32 & $6.5(2$ to 15$)$ & & 31 & $0(0$ to 1$)$ & & 31 & $1(0$ to 5$)$ & \\
\hline $\mathrm{Ile} / \mathrm{Val}+\mathrm{Val} / \mathrm{Val}$ & 17 & $5(1$ to 12$)$ & & 14 & $0(0$ to 1$)$ & & 14 & $1(0$ to 3$)$ & \\
\hline GSTP1 exon6 & & & 0.645 & & & 0.658 & & & 0.234 \\
\hline Ala/Ala & 43 & $6(1$ to 15$)$ & & 41 & $0(0$ to 1$)$ & & 41 & $1(0$ to 5$)$ & \\
\hline $\mathrm{Ala} / \mathrm{Val}+\mathrm{Val} / \mathrm{Val}$ & 6 & $6.5(1$ to 12$)$ & & 4 & $0(0$ to 0$)$ & & 4 & $0.5(0$ to 1$)$ & \\
\hline$E P H X 1$ exon 3 & & & 0.317 & & & 0.954 & & & 0.531 \\
\hline Tyr/Tyr & 27 & $6(2$ to 15$)$ & & 22 & $0(0$ to 1$)$ & & 22 & $1(0$ to 5$)$ & \\
\hline Tyr/His+His/His & 22 & $6(1$ to 12$)$ & & 23 & $0(0$ to 1$)$ & & 23 & $1(0$ to 4$)$ & \\
\hline$E P H X 1$ exon 4 & & & 0.099 & & & 0.066 & & & 0.265 \\
\hline His/His & 35 & $7(1$ to 15$)$ & & 30 & $0(0$ to 1$)$ & & 30 & $1(0$ to 5$)$ & \\
\hline His/Arg+Arg/Arg & 14 & $4.5(2$ to 11$)$ & & 15 & $0(0$ to 0$)$ & & 15 & $1(0$ to 3$)$ & \\
\hline
\end{tabular}

frequencies in peripheral blood lymphocytes reflect accumulated chromosomal damage $(35,36)$, whereas urinary 1-OHP reflects exposure within the last $24 \mathrm{~h}$.
Even though genetic polymorphisms of biomarkers of susceptibility may play a role in genetic damage involved in mutagenesis and carcinogenesis (7), only a few studies have investigated the influence of PAH 
Table $6 C B M N$, (CA-gap), and (CA+gap) frequencies in coke oven workers by genotype

\begin{tabular}{|c|c|c|c|c|c|c|c|c|c|}
\hline \multirow[b]{2}{*}{ Genotypes } & \multicolumn{3}{|c|}{ CBMN / \%o } & \multicolumn{3}{|c|}{ CA-gap / \% } & \multicolumn{3}{|c|}{ CA+gap / \% } \\
\hline & $n$ & $\begin{array}{l}\text { Median } \\
\text { (Range) }\end{array}$ & $p$ & $n$ & $\begin{array}{l}\text { Median } \\
\text { (Range) }\end{array}$ & $p$ & $n$ & $\begin{array}{l}\text { Median } \\
\text { (Range) }\end{array}$ & $p$ \\
\hline CYP1A1 exon 7 & & & 0.015 & & & 0.577 & & & 0.719 \\
\hline Ile/Ile & 43 & $14(4$ to 38$)$ & & 43 & $0(0$ to 7$)$ & & 43 & $3(0$ to 9$)$ & \\
\hline Ile/Val+Val/Val & 6 & $9(8$ to 10$)$ & & 5 & $1(0$ to 2$)$ & & 5 & $2(1$ to 5$)$ & \\
\hline CYP1B1 exon3 & & & 0.094 & & & 0.218 & & & 0.266 \\
\hline Asn/Asn & 24 & $15(4$ to 38$)$ & & 25 & $1(0$ to 3$)$ & & 25 & $3(0$ to 7$)$ & \\
\hline Asn/Ser+Ser/Ser & 25 & 11 (4 to 26$)$ & & 23 & $0(0$ to 7$)$ & & 23 & $2(0$ to 9$)$ & \\
\hline GSTM1 & & & 0.127 & & & 0.455 & & & 0.883 \\
\hline Null & 25 & $10(4$ to 28$)$ & & 24 & $1(0$ to 3$)$ & & 24 & $3(0$ to 8$)$ & \\
\hline Positive & 24 & $14(7$ to 38$)$ & & 24 & $0(0$ to 7$)$ & & 24 & $3(0$ to 9$)$ & \\
\hline GSTT1 & & & 0.213 & & & 0.580 & & & 0.828 \\
\hline Null & 6 & $9(4$ to 23$)$ & & 5 & $0(0$ to 1$)$ & & 5 & $3(0$ to 5$)$ & \\
\hline Positive & 42 & $13(5$ to 38$)$ & & 42 & $1(0$ to 7$)$ & & 42 & $3(0$ to 9$)$ & \\
\hline GSTP1 exon5 & & & 0.729 & & & 0.216 & & & 0.932 \\
\hline Ile/Ile & 29 & $12(4$ to 38$)$ & & 28 & $1(0$ to 7$)$ & & 28 & $2.5(0$ to 9$)$ & \\
\hline Ile/Val+Val/Val & 20 & $13(5$ to 26$)$ & & 20 & $0(0$ to 2$)$ & & 20 & $3(0$ to 8$)$ & \\
\hline GSTP1 exon6 & & & 0.967 & & & 0.249 & & & 0.775 \\
\hline Ala/Ala & 42 & $12(4$ to 38$)$ & & 41 & $1(0$ to 7$)$ & & 41 & $3(0$ to 9$)$ & \\
\hline $\mathrm{Ala} / \mathrm{Val}+\mathrm{Val} / \mathrm{Val}$ & 7 & $13(5$ to 26$)$ & & 7 & $0(0$ to 1$)$ & & 7 & $4(0$ to 8$)$ & \\
\hline$E P H X 1$ exon3 & & & 0.305 & & & 0.455 & & & 0.883 \\
\hline Tyr/Tyr & 23 & $14(7$ to 26$)$ & & 24 & $0(0$ to 7$)$ & & 24 & $3(1$ to 9$)$ & \\
\hline Tyr/His+His/His & 26 & $11(4$ to 38$)$ & & 24 & $1(0$ to 3$)$ & & 24 & $3(0$ to 7$)$ & \\
\hline$E P H X 1$ exon 4 & & & 0.852 & & & 0.750 & & & 0.370 \\
\hline His/His & 37 & $12(4$ to 38$)$ & & 36 & $0.5(0$ to 7$)$ & & 36 & $2.5(0$ to 9$)$ & \\
\hline His/Arg+Arg/Arg & 12 & $13(7$ to 26$)$ & & 12 & $0.5(0$ to 1$)$ & & 12 & $3(1$ to 8$)$ & \\
\hline
\end{tabular}

metabolising enzyme polymorphisms (namely, EPHX1 exon 3, CYP1A1, GSTM1, GSTT1, and GSTP1 exon 5) on CBMN (11-13) and only one study (of GSTM1 and NAT2) (14) on CA frequency in coke oven workers.

In this respect, our study was the first to attempt a comprehensive approach to the issue with eight $\mathrm{PAH}$ metabolising enzyme polymorphisms. Their distribution across the study population was similar to earlier reports in Turkish and European Caucasian populations (37-39). The only polymorphism that stands out in our study is the wild-type CYP1A1 exon 7 which was associated with a significantly higher CBMN frequency. At this stage, the reasons behind this finding are unclear. It is possible that PAHexposed individuals with the wild-type genotype could activate $\mathrm{PAHs}$, benzo(a)pyrene (BaP) in particular, to their toxic intermediates at higher rates than individuals carrying variant genotypes. In fact, Zhang et al. (40) have reported a higher rate of $\mathrm{BaP}$ metabolism in vitro with the wild-type than mutant gene at high $\mathrm{BaP}$ concentrations. Alternatively, it is also possible that mutant allele carriers are so few that any (low or high) CBMN frequency finding is a product of pure chance. Moreover, our findings could have been influenced by confounding factors such as other polymorphisms, smoking, and age, since multiple linear regression analysis revealed no significant influence of this gene polymorphism on CBMN frequency, and neither have earlier studies $(12,13,18)$.

This lack of association was also noted between other gene polymorphisms and CBMN frequencies, which is consistent with studies in coke oven workers in regard to $\operatorname{GSTM1}(11,12,18)$ and GSTT1 polymorphisms (11-13).

In contrast to our findings, Leng et al. (12) reported a significantly higher CBMN frequencies with the GSTP1 Val/Val genotypes and significantly lower CBMN frequencies with the EPHXI exon 3 mutated genotypes.

Associations between the gene polymorphisms and CA frequencies in our study were also not significant 
Table 7 Relationships between biomarkers of exposure (1-OH pyrene) and effects

\begin{tabular}{lcccc}
\hline \multirow{2}{*}{ Variables } & \multicolumn{2}{c}{ Exposed Group } & \multicolumn{2}{c}{ Control Group } \\
\cline { 2 - 5 } & $\mathbf{r}$ & $\boldsymbol{p}$ & $\mathbf{r}$ & $\boldsymbol{p}$ \\
\hline CBMN & 0.228 & 0.114 & -0.008 & 0.954 \\
\hline CA-gap & & & -0.048 & 0.755 \\
\hline & 0.116 & 0.431 & & 0.492 \\
\hline CA+gap & 0.207 & 0.158 & -0.106 & \\
\hline
\end{tabular}

Table 8 Multiple linear regression analyses of cytogenetic data

\begin{tabular}{|c|c|c|c|c|c|}
\hline \multirow{2}{*}{$\begin{array}{l}\text { Dependent } \\
\text { Variables }\end{array}$} & \multirow{2}{*}{$\begin{array}{l}\text { Independent } \\
\text { Variables }\end{array}$} & \multirow{2}{*}{$\begin{array}{l}\text { Coefficient of } \\
\text { Regression (B) }\end{array}$} & \multirow{2}{*}{$p$ value } & \multicolumn{2}{|c|}{$95 \%$ CI for (B) } \\
\hline & & & & Lower & Upper \\
\hline \multirow[t]{6}{*}{$C B M N$} & Coke oven workers & 0.724 & $<0.001$ & 0.478 & 0.971 \\
\hline & Age & 0.006 & 0.372 & -0.008 & 0.020 \\
\hline & Smoking & 0.037 & 0.511 & -0.074 & 0.148 \\
\hline & $1-O H P$ & 0.056 & 0.079 & -0.007 & 0.119 \\
\hline & $C Y P 1 A 1^{a}$ & -0.290 & 0.086 & -0.622 & 0.042 \\
\hline & $G S T T 1^{b}$ & -0.243 & 0.100 & -0.534 & 0.048 \\
\hline \multirow[t]{6}{*}{$C A$-gap } & Coke oven workers & 0.268 & 0.005 & 0.082 & 0.454 \\
\hline & Age & -0.006 & 0.297 & -0.016 & 0.005 \\
\hline & Smoking & 0.004 & 0.922 & -0.081 & 0.089 \\
\hline & $1-O H P$ & 0.037 & 0.122 & -0.010 & 0.084 \\
\hline & $G S T T 1^{b}$ & -0.184 & 0.124 & -0.418 & 0.051 \\
\hline & EPHX1 exon $4^{a}$ & -0.088 & 0.315 & -0.260 & 0.085 \\
\hline \multirow[t]{5}{*}{$C A+g a p$} & Coke oven workers & 0.440 & 0.002 & 0.167 & 0.712 \\
\hline & Age & 0.000 & 0.955 & -0.015 & 0.016 \\
\hline & Smoking & -0.053 & 0.399 & -0.177 & 0.071 \\
\hline & 1-OHP & 0.052 & 0.140 & -0.017 & 0.120 \\
\hline & GSTT1 $^{b}$ & -0.308 & 0.077 & -0.651 & 0.034 \\
\hline
\end{tabular}

${ }^{a}$ Wild-type genotype served as reference

${ }^{b}$ Positive genotype served as reference

in either coke oven or control workers. Kalina et al. (14) reported similar findings for GSTMI polymorphisms.

Multiple linear regression analysis identified work at coke oven as the single contributing factor to increased CBMN, CA+gap, and CA-gap frequencies and confirmed that occupational exposure has the major effect on CBMN and CA frequencies, as reported earlier by Qiu et al. (13).

It is well known that individual response to certain genotoxic chemicals may also be influenced by DNA repair and cell cycle control $(31,41)$, which calls for further investigation in that direction.

In conclusion, our study has confirmed positive association between increased genetic damage and occupational exposure but not with the genetic polymorphisms of PAH metabolising enzymes in Turkish coke oven workers. However, due to the limited sample size, our findings need to be verified in further studies with a larger sample.

\section{Acknowledgement}

This study was supported by the Research Funds of Gazi University (Grant No. SBE-11/2002-5) and Ankara University (Grant No. 2001-08-03-025) and the Turkish Scientific and Technical Research Council (Grant no: SBAG-AYD-350). The authors wish to thank all the workers who participated in this study and Mr Salih Ergocen for running the statistical analysis. 


\section{REFERENCES}

1. International Agency for Research on Cancer (IARC). Polycyclic Aromatic Hydrocarbons. Part 1. Chemical, Environmental and Experimental Data. Monographs on the Evaluation of the Carcinogenic Risk of Chemicals to Humans. Vol. 32. Lyon: IARC; 1983.

2. International Agency for Research on Cancer (IARC). Polycyclic Aromatic Hydrocarbons. Part 3. Industrial Exposure in Aluminum Production, Coal Gasification, Coke Production, and Iron and Dteel Founding. Monographs on the Evaluation of the Carcinogenic Risk of Chemicals to Humans. Vol. 34. Lyon: IARC; 1984.

3. Bonassi S, Norppa H, Ceppi M, Strömberg U, Vermeulen R, Znaor A, Cebulska-Wasilewska A, Fabianova E, Fucic A, Gundy S, Hansteen IL, Knudsen LE, Lazutka J, Rossner P, Sram RJ, Boffetta P. Chromosomal aberration frequency in lymphocytes predicts the risk of cancer: results from a pooled cohort study of 22,358 subjects in 11 countries. Carcinogenesis 2008;29:1178-83. doi: 10.1093/carcin/bgn075

4. Bonassi S, Znaor A, Ceppi M, Lando C, Chang WP, Holland N, Kirsch-Volders M, Zeiger E, Ban S, Barale R, Bigatti MP, Bolognesi C, Cebulska-Wasilewska A, Fabianova E, Fucic A, Hagmar L, Joksic G, Martelli A, Migliore L, Mirkova E, Scarfi MR, Zijno A, Norppa H, Fenech M, An increased micronucleus frequency in peripheral blood lymphocytes predicts the risk of cancer in humans. Carcinogenesis 2007;28:625-31. doi:10.1093/carcin/bgl177

5. Murgia E, Ballardin M, Bonassi S, Rossi AM, Barale R. Validation of micronuclei frequency in peripheral blood lymphocytes as early cancer risk biomarker in a nested casecontrol study. Mutat Res 2008;639:27-34. doi: 10.1016/j. mrfmmm.2007.10.010

6. Wang Y, Yang H, Li L, Wang H, Xia X, Zhang C. Biomarkers of chromosomal damage in peripheral blood lymphocytes induced by polycyclic aromatic hydrocarbons: a metaanalysis. Int Arch Occup Environ Health 2012;85:13-25. doi: doi: 10.1007/s00420-011-0629-4

7. Norppa h. Cytogenetic biomarkers and genetic polymorphisms. Toxicol Lett 2004;149:309-34. doi: 10.1016/j. toxlet.2003.12.042

8. Iarmarcovai G, Bonassi S, Botta A, Baan RA, Orsière T Genetic polymorphisms and micronucleus formation: a review of the literature. Mutat Res 2008;658:215-33. doi: 10.1016/j.mrrev.2007.10.001

9. Rihs HP, Pesch B, Kappler M, Rabstein S, Rossbach B, Angerer J, Scherenberg M, Adams A, Wilhelm M, Seidel A, Brüning T. Occupational exposure to polycyclic aromatic hydrocarbons in German industries: association between exogenous exposure and urinary metabolites and its modulation by enzyme polymorphisms. Toxicol Lett 2005;157:241-55. PMID: 15917149

10. Ada AO, Yilmazer M, Suzen S, Demiroglu C, Demirbag AE, Efe S, Alemdar Y, Burgaz S, Iscan M. Cytochrome P450 (CYP) and glutathione S-transferases (GST) polymorphisms (CYP1A1, CYP1B1, GSTM1, GSTP1 and GSTT1) and urinary levels of 1-hydroxypyrene in Turkish coke oven workers. Genet Mol Biol 2007;30:511-9. doi: 10.1590/ S1415-47572007000400002

11. van Delft JH, Steenwinkel MS, van Asten JG, de Vogel N, Bruijntjes-Rozier TC, Schouten T, Cramers P, Maas L, van Herwijnen MH, van Schooten F, Hopmans PM. Biological monitoring the exposure to polycyclic aromatic hydrocarbons of coke oven workers in relation to smoking and genetic polymorphisms for GSTM1 and GSTT1. Ann Occup Hyg 2001;45:395-408. PMID: 11418090

12. Leng S, Dai Y, Niu Y, Pan Z, Li X, Cheng J, He F, Zheng Y. Effects of genetic polymorphisms of metabolic enzymes on cytokinesis-block micronucleus in peripheral blood lymphocyte among coke-oven workers. Cancer Epidemiol Biomarkers Prev 2004;13:1631-9. PMID: 15466980

13. Qiu L, Leng S, Wang Z, Dai Y, Zheng Y, Wang Z. Path analysis of biomarkers of exposure and early biological effects among coke-oven workers exposed to polycyclic aromatic hydrocarbons. Cancer Epidemiol Biomarkers Prev 2007;16:1193-9. doi: 10.1158/1055-9965.EPI-07-0001

14. Kalina I, Brezani P, Gajdosova D, Binkova B, Salagovic J, Habalova V, Mrackova G, Dobias L, Sram RJ. Cytogenetic monitoring in coke oven workers. Mutat Res 1998;417:9-17. PMID: 9729241

15. Marczynski B, Pesch B, Wilhelm M, Rossbach B, Preuss R, Hahn JU, Rabstein S, Raulf-Heimsoth M, Seidel A, Rihs HP, Adams A, Scherenberg M, Erkes A, Engelhardt B, Straif K, Kafferlein HU, Angerer J, Brüning T. Occupational exposure to polycyclic aromatic hydrocarbons and DNA damage by industry: a nationwide study in Germany. Arch Toxicol 2009;83:947-57. doi: 10.1007/s00204-009-0444-9

16. Duan H, Leng S, Pan Z, Dai Y, Niu Y, Huang C, Bin P, Wang Y, Liu Q, Chen W, Zheng Y. Biomarkers measured by cytokinesis-block micronucleus cytome assay for evaluating genetic damages induced by polycyclic aromatic hydrocarbons. Mutat Res 2009;677:93-9. doi: 10.1016/j. mrgentox.2009.06.002

17. Siwinska E, Mielzynska D, Kapka L. Association between urinary 1-hydroxypyrene and genotoxic effects in coke oven workers. Occup Environ Med 2004;61:e10. PMID: 14985527

18. Brescia G, Celotti L, Clonfero E, Neumann GH, Forni A, Foà V, Pisoni M, Ferri GM, Assennato G. The influence of cytochrome P450 1A1 and glutathione S-transferase M1 genotypes on biomarker levels in coke-oven workers. Arch Toxicol 1999;73:431-9. PMID: 10650914

19. Yilmazer M, Ada AO, Suzen S, Demiroglu C, Demirbag AE, Efe S, Alemdar Y, Iscan M, Burgaz S. Biological monitoring of environmental exposure to polycyclic aromatic hydrocarbons: 1-hydroxypyrene in urine of Turkish coke oven workers. Bull Environ Contam Toxicol 2006;76:559-65. doi: 10.1007/s00128-006-0956-4

20. Fenech M. The cytokinesis-block micronucleus technique: a detailed description of the method and its application to genotoxicity studies in human populations. Mutat Res 1993;285:35-44. doi: 10.1016/0027-5107(93)90049-L

21. Eastmond DA, Tucker JD. Identification of aneuploidyinducing agents using cytokinesis-blocked human lymphocytes and an antikinetochore antibody. Environ Mol Mutagen 1989; 13:34-43. doi: 10.1002/em.2850130104

22. Cascorbi I, Brockmöller J, Roots I. A C4887A polymorphism in exon 7 of human CYP1A1: population frequency, mutation linkages, and impact on lung cancer susceptibility. Cancer Res 1996;56:4965-9. PMID: 8895751

23. Bailey LR, Roodi N, Dupont WD, Parl FF. Association of cytochrome P450 1B1 (CYP1B1) polymorphism with steroid receptor status in breast cancer. Cancer Res 1998;58:5038-41. PMID: 9823305 
24. Smith CA, Harrison DJ. Association between polymorphism in gene for microsomal epoxide hydrolase and susceptibility to emphysema. Lancet 1997;350:630-3. doi: 10.1016/S01406736(96)08061-0

25. Abdel-Rahman SZ, el-Zein RA, Anwar WA, Au WW. A multiplex PCR procedure for polymorphic analysis of GSTM1 and GSTT1 genes in population studies. Cancer Lett 1996;107:229-33. doi: 10.1016/0304-3835(96)04832-X

26. Park JY, Schantz SP, Stern JC, Kaur T, Lazarus P. Association between glutathione S-transferase pi genetic polymorphisms and oral cancer risk. Pharmacogenetics 1999;9;497-504 PMID: 10780269 Erratum in: Pharmacogenetics 2000;10:371.

27. Bonassi S, Ugolini D, Kirsch-Volders M, Strömberg U, Vermeulen R, Tucker JD. Human population studies with cytogenetic biomarkers: review of the literature and future prospectives. Environ Mol Mutagen 2005;45:258-70. doi: 10.1002/em.20115

28. Jongeneelen FJ, van Leeuwen FE, Oosterink S, Anzion RB, van der Loop F, Bos RP, van Veen HG. Ambient and biological monitoring of coke oven workers: determinants of the internal dose of polycyclic aromatic hydrocarbons. $\mathrm{Br}$ J Ind Med 1990;47:454-61. PMCID: PMC1035206

29. Van Hummelen P, Gennart JP, Buchet JP, Lauwerys R, Kirsch-Volders M. Biological markers in PAH exposed workers and controls. Mutat Res 1993;300:231-9. PMID: 7687023

30. Forni A, Guanti G, Bukvic N, Ferri G, Foà V. Cytogenetic studies in coke oven workers. Toxicol Lett 1996;88:185-9. doi: 10.1016/0378-4274(96)03736-8

31. Wang F, He Y, Guo H, Li J, Yang Y, Wu Z, Zheng H, Wu T. Genetic variants of nucleotide excision repair genes are associated with DNA damage in coke oven workers. Cancer Epidemiol Biomarkers Prev 2010;19:211-8. doi: 10.1158/1055-9965.EPI-09-0270

32. Kuljukka-Rabb T, Nylund L, Vaaranrinta R, Savela K, Mutanen P, Veidebaum T, Sorsa M, Rannug A, Peltonen K. The effect of relevant genotypes on PAH exposure-related biomarkers. J Expo Anal Environ Epidemiol 2002;12:81-91. PMID: 11859435
33. Bender MA, Leonard RC, White O Jr, Costantino JP, Redmond CK. Chromosomal aberrations and sister-chromatid exchanges in lymphocytes from coke oven workers. Mutat Res 1988;206:11-6. PMID: 3412368

34. Topaktaş M, Rencüzoğullari E, Ila HB, Kayraldiz A. Chromosome aberration and sister chromatid exchange in workers of the Iron and Steel Factory of Iskenderun, Turkey. Teratog Carcinog Mutagen 2002;22:411-23. PMID: 12395403

35. Tucker JD, Preston RJ. Chromosome aberrations, micronuclei, aneuploidy, sister chromatid exchanges, and cancer risk assessment. Mutat Res 1996;365:147-59. doi: 10.1016/ S0165-1110(96)90018-4

36. van Delft JH, Baan RA, Roza L. Biological effect markers for exposure to carcinogenic compound and their relevance for risk assessment. Crit Rev Toxicol 1998;28:477-510. PMID: 9793748

37. Ada AO, Süzen SH, Iscan M. Polymorphisms of cytochrome P450 1A1, glutathione S-transferases M1 and T1 in a Turkish population. Toxicol Lett 2004;151:311-5. doi: 10.1016/ j.toxlet.2003.12.075

38. Ada AO, Süzen HS, Iscan M. Polymorphisms of microsomal epoxide hydrolase and glutathione S-transferase $\mathrm{P} 1$ in a male Turkish population. Int J Toxicol 2007;26:41-6. doi: 10.108 $0 / 10915810601118222$

39. Ada AO, Kunak SC, Hancer F, Soydas E, Alpar S, Gulhan M, Iscan M. Association between GSTM1, GSTT1, and GSTP1 polymorphisms and lung cancer risk in a Turkish population. Mol Biol Rep 2012;39:5985-93. doi: 10.1007/ s11033-011-1411-0

40. Zhang ZY, Fasco MJ, Huang L, Guengerich FP, Kaminsky LS. Characterization of purified human recombinant cytochrome P4501A1-Ile ${ }^{462}$ and -Val ${ }^{462}$ : assessment of a role for the rare allele in carcinogenesis. Cancer Res 1996;56:392633.

41. Dhillon VS, Thomas P, Iarmarcovai G, Kirsch-Volders M, Bonassi S, Fenech M. Genetic polymorphisms of genes involved in DNA repair and metabolism influence micronucleus frequencies in human peripheral blood lymphocytes. Mutagenesis 2011;26:33-42. doi: 10.1093/ mutage/geq076 


\section{Sažetak}

CITOGENETIČKO OŠTEĆENJE U TURSKIH RADNIKA NA KOKSNIM PEĆIMA IZLOŽENIH POLICIKLIČKIM AROMATSKIM UGLJIKOVODICIMA: POVEZANOST S GENSKIM POLIMORFIZMIMA CYP1A1, CYP1B1, EPHX1, GSTM1, GSTT1 I GSTP1

Cilj je ovog ispitivanja bio utvrditi učestalost kromosomskih aberacija (CA) i mikronukleusa (CBMN) u limfocitima periferne krvi turskih radnika na koksnim pećima te utjecaj genskih polimorfizama CYP1A1, CYP1B1, EPHX1, GSTM1, GSTT1 i GSTP1 na te biopokazatelje. Profesionalna je izloženost ovih radnika značajno povećala učestalost CA i CBMN, ali genski polimorfizmi nisu utjecali na ove parametre bez obzira na to je li se radilo o radnicima ili o kontrolnoj skupini. Međutim, značaj je naših rezultata ograničen zbog malog uzorka te su potrebna daljnja istraživanja s većim uzorkom da ih se potvrdi.

KLJUČNE RIJEČI: biopokazatelji, kromosomske aberacije, mikronukleusi, profesionalna izloženost

\section{CORRESPONDING AUTHOR:}

Sema Burgaz

Department of Toxicology, Faculty of Pharmacy,

Gazi University

Etiler, Ankara, Turkey

E-mail:burgaz@gazi.edu.tr 